\title{
Long Distance Commuting in Oil and Gas Production Industry in the Northwestern Siberia: Sociological Analysis of Change
}

\author{
Anatoly N. Silin \\ Tyumen State Oil and Gas University, Russian Federation \\ Email:sm-2004@rambler.ru
}

\section{Doi:10.5901/mjss.2015.v6n3s5p199}

\begin{abstract}
Article considers social aspects of a long distance commuting in an oil and gas complex of Northwestern Siberia. The history of its development, change of conceptual approaches to the organization of shifts, change in dynamics of key parameters are shown. The interaction system of basic elements of rotational work is revealed and the management mechanism is offered. The results of sociological researches conducted in the oil and gas companies situated in Northwest Siberia are given. The necessity of the strengthening interdisciplinary researches directed on leveling of negative social aspects of a long distance commuting as well as the system of sociological monitoring are proved.
\end{abstract}

Keywords: long distance commuting, sociological analysis and monitoring, Northwestern Siberia, interdisciplinary research, oil and gas production

\section{Introduction}

The critical necessity for nonconventional forms of the work organization, corresponding to complex challenges of production in the low-mastered territories with extreme climatic conditions arose since the beginning of the intensive oil and gas complex formation in the Northwestern Siberia. It was required to provide profitability, high mobility of labor resources, and the presence of full amount of necessary specialists of necessary trades.

Except the absence of manufacturing, construction and raw, communication and labor resources of the undeveloped territories, the problem of extreme climatic conditions of the territories development was rafter critical as the main volume of oil and gas fields are located in high widths of the circumpolar region of the country. A long distance commuting method oil, work organization is occurred to be the only acceptable way for the organization of production in such conditions. Long distance commuting method of the work organization is known for a long time in Russia and in other countries. The notion "shift" is taken from the marine terminology where it means "to be on duty on the ship", providing a service continuity. The term received subsequently the broader application and in other spheres of activity, its synonym is "change" (Storey, 2001; 2008; 2010).

In the world practice, this form of the labor organization is widely used of developing of new territories, building of large industrial and infrastructure facilities in remote areas, and in the industry, mainly, extracting and timber, and also in the seasonal types of activity, e.g. geology and some other. The long distance commuting method differs from of the replaceable organization of work by performance of necessary works by forces of changed mobile divisions which are regularly leaving on objects, remote from location of the enterprises so that daily return of workers to the constant place of residence becomes either impossible, or economically inexpedient. In Russia for the first time the long distance commuting method was widely applied at the beginning of the 1950s of the last century when Kamni oil field in the Caspian Sea was developed.

Taking into account the necessity of new low-populated territories development the idea of "a rotational and forwarding method" was realized in the late sixties of the last century. The purpose and the main task were to provide new remote work places with the qualified personnel from other regions.

The interregional form of a rotational and forwarding method in the Tyumen North for the first time was experimentally introduced in vast scales in Karsky oil and gas prospecting expedition in 1974 when regularly replaced rotational crews took off for work from Tyumen to Yamal (Harasavey) (Silin, 2011).

From the 30s of the last century, the beginning of the Soviet colonization of the Far North, the following model of development was accepted. Near a new field (or groups of fields) the new city was constructed. So Norilsk was created, Nadym and Pangoda were built while developing the Medvezhie field, near the Urengoy field - Novy Urengoy, Samotlor 
- Nizhnevartovsk and Megion, etc.

In the region, the unique town-planning system differentiated on the non-uniform territory of the Tyumen North was created. So, if in the Middle ob Area near each middle-sized and a large-scale oil field the city was created therefore less than in two decades there were 17 new cities and tens of working settlements. The other situation was developed in gas regions of Subpolar zone and the Polar region. That was here for the first time in the country there was an innovative category of settlements i.e. rotational settlements - Pangoda in the Nadym area, Yamburg and Novozapolarny in Tazovsky district of the Yamalo-Nenets Autonomous Area, Vyngapurovsky in Noyabrsk area, Pionerny in the Tomsk region, etc. appeared.

As a result if in Khanty-Mansi Autonomous District there was an extensive network of settlements, there were new large cities of Khanty-Mansiysk, Nefteyugansk, Surgut, Kogalym, Langepas and others, in the Yamalo-Nenets Autonomous District only Novy Urengoy, Nadym and Noyabrsk were constructed.

At that moment as for the income level for inhabitants of northern settlements in the Tyumen region during the Soviet period of an oil and gas complex formation considerably advanced other Russian regions, however on quality of life and development of social infrastructure compensation seriously lagged behind. Hard frosts, low-quality water, midges, lack of fresh vegetables and fruit, lack of oxygen - it is not the full list of life features in the north for which a salary was higher, than in the central and southern regions of the country.

The Russian North as a whole and the northern part of the Tyumen region in particular differs quite high in population density in places of natural resources development (in Khanty-Mansi Autonomous District - 2.9, in the Yamalo-Nenets Autonomous Area - 0.7 persons per $1 \mathrm{sq} . \mathrm{km}$ ) in comparison with other countries. At the same time, there is practically no qualified staff of oil and gas developers among peoples constantly living on the North. Meanwhile, the population of Khanty-Mansi Autonomous District for the last quarter of the century of intensive development increased by 5 times, the Yamalo-Nenets Autonomous District by six times and made in 2010 the first 1528.6 thousand people, the second -546.5 thousand people (Belonozhko \& Silin, 2013).

Thus, the relevance of the study of long distance commuting method comprises, firstly, the need for a sharp increase in the use of non-traditional forms of work organization both in the North of Western Siberia, and in other regions of the world, such as Canada and Australia. Secondly, the massive use of mobile labor, in addition to the obvious economic feasibility, is connected with diverse social consequences, the emergence of already significant and yet latent social processes that require identification, research and create technologies to neutralize the negative impact of the long distance commuting, to improve the quality of life of people working in such mode. These are the goals the author set.

\section{Rejection of the Old Concepts and Groundlessness of the New One}

Change of the development concept in Russia happened only in the mid-eighties - 20 years after the beginning of the West Siberian oil and gas complex formation. Novy Urengoy became the last large city created within the accepted model of development. When developing the following gas giant - Yamburg the rotational model was assumed as a basis. The new city was not built, from the very beginning the settlement of Yamburg was created as rotational, considering accommodation of the personnel without families with reduced free time. Therefore, at the same time with the restriction amount of main objects of the social infrastructure, some functions of life support in it are expanded, in particular the sphere of food and the consumer services, usually carried out by a family. For ensuring mobility, the rotational settlements are equipped with the facilitated and collapsible modules of high factory readiness degree, as a rule, equipped with built-in or complete delivered utility equipment, furniture, stock.

Nowadays, legislatively, the long distance commuting method is regulated by the Labor Code of the Russian Federation, which determines the duration of shifts and the work schedule, the system of payment and extra charges, length of service of the rotational personnel and some general restrictions when using this method. It should be noted, that the code does not establish standards of medical care and industrial hygiene, the organization of the rotational settlement, food for workers, etc.

Thus, the Labor Code defines some principles of the rotational work organization and in each case it is necessary to carry out the sociological, economic, medico biological and other researches realizing interdisciplinary approach for adoption of administrative decisions and necessary regulating documents by all interacting power bodies, connected with the rotational work organization (the management of companies, administrations of northern territories, other federal, regional and municipal structures).

Recently the government power structures have actually refused of the regulation of rotational work organization and assigned all to the private companies. Scientific researches of shifts were reduced also. In Russia in recent years, no conferences devoted to the problems of research of rotational work were held. Meanwhile, many countries, on the 
contrary, speed up this kind of work. Especially large interdisciplinary researches are conducted in Australia and Canada, and also at the Vienna University (Eilmsteiner-Saxinger, 2011; 2013; Beach et al., 2003; Buscher \& Urry, 2009).

\section{The Need for Integrated Research}

In order to get ready for that it is necessary today to pay attention to the urgency of carrying out interdisciplinary scientific and analytical researches of all problems connected with the large-scale usage of the rotational work (Mokenzie \& Hoath, 2013; Olwig \& Sorensen, 2002).

It is necessary, having revealed all designated in rotational practice and still latent problems to define their hierarchy and interaction and to find possible solutions, estimating their efficiency. Anyway, they are connected with various elements of the rotational work organization (figure 1) and the management mechanism (figure 2) consisting of three blocks reflecting firstly the rotational personnel activity in the place of residence, secondly, in a place of work and, thirdly, in the process of commuting from one place to the other.

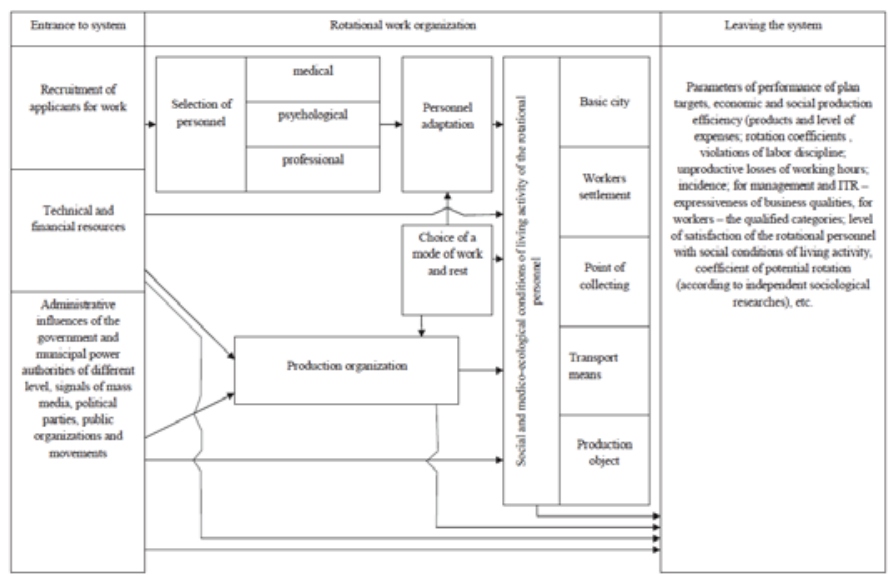

Figure 1. Interaction of the elements of rotational work

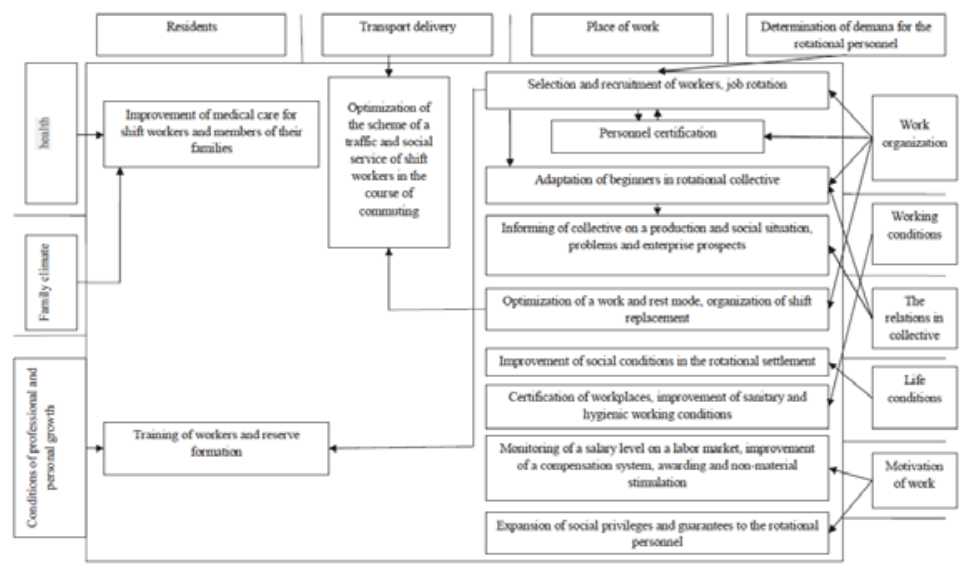

Figure 2. Mechanism of managing rotational work

Research of a long distance commuting method must have an interdisciplinary character and include a wide range of questions, for example, norms of nutrition, the esthetic solution of sociocultural space in rotational settlements, psychological features of rotational work, etc. (Southcott, 2013; Hilti, 2009; Khaytun, 2013). Therefore, the latter note 
significant (as the information and visual) difficulties connected with the rotational work owing to insufficient spatial and excess time frames, and social and psychological as a result of the long social isolation in a small group.

Life in movement, a mobile way of life of commuters demand continuous complex researches of sociologists, psychologists, physiologists, jurists, anthropologists, representatives of other scientific directions. Long distance commuters estimate their life, as "consisting of two halves" or simply "double" (Weichhart, 2009; Schier, 2013).

\section{Findings and Discussion}

It should be noted that figures of a long distance commuting method usage in Russia, since 60 of the last century constantly increased. Only during the Post-Soviet period, from 1991 to 2011 they increased, by more than three times and today every fourth worker at the territory of the Yamalo-Nenets Autonomous District a shift worker. On the Northwest of Siberia as a whole, the share of the rotational personnel is slightly lower, but exceeds $10 \%$ of total number of employed. Workers from well-known oil and gas extraction regions (Bashkiria, Tataria), and inhabitants of the stagnating Russian remote places and CIS countries for whom it is the only way of a survival arrive there for work. Volumes of interregional use in the West Siberian North of a labor force of other areas increase today (tab. 1 and 2) and in even bigger degree, considering the planned amounts of works on Yamal and a shelf of the North Sea development, will increase during the sort going period.

Table 1. The number of long distance commuters in the territory of the Khanty-Mansi District (Yugra), thousands people

\begin{tabular}{lcccc}
\hline \multirow{2}{*}{\multicolumn{1}{c}{ Industry }} & \multicolumn{2}{c}{2009} & 2010 & 2011 \\
\cline { 2 - 5 } & Total & Including interregional form & Total & Total \\
\hline Including & 69.3 & 65.1 & 72.3 & 69.7 \\
\hline Production of energy resources & 35.8 & 32.8 & 48.9 & 48.5 \\
\hline Prospecting works & 3.1 & 2.9 & - & - \\
\hline Construction (including drilling) & 20.9 & 20.1 & 11.1 & 9.1 \\
\hline Transport and communication & 5.7 & 5.6 & 6.2 & 6.0 \\
\hline Power industry & 2.2 & 2.1 & 1.7 & 1.7 \\
\hline Social infrastructure & 5.5 & 5.3 & 3.2 & 1.3 \\
\hline
\end{tabular}

Source: based on Rosstat, 2012

Table 2. The number long distance commuters in on the territory of the Yamalo-Nenets Autonomous District, thousand people

\begin{tabular}{lcccccccc}
\hline \multirow{2}{*}{ Industry } & \multicolumn{2}{c}{2009} & & 2010 & 2011 & 2012 \\
\cline { 2 - 9 } & Total & $\begin{array}{c}\text { Including } \\
\text { interregional form }\end{array}$ & Total & $\begin{array}{c}\text { Including } \\
\text { interregional form }\end{array}$ & Total & $\begin{array}{c}\text { Including } \\
\text { interregional form }\end{array}$ & $\begin{array}{c}\text { Total } \\
\text { including } \\
\text { interregional form }\end{array}$ \\
\hline Total & 84.1 & 66.3 & 75.5 & 58.7 & 82.9 & 63.9 & 90.1 & 71.3 \\
\hline Workers & 68.7 & 54.1 & 62.0 & 48.4 & 69.6 & 54.1 & 75.7 & 60.5 \\
\hline $\begin{array}{l}\text { Energy resources } \\
\text { production }\end{array}$ & 27.5 & 18.4 & 27.6 & 18.5 & 26.9 & 17.0 & 27.0 & 16.7 \\
\hline $\begin{array}{l}\text { Construc-tion } \\
\text { Transport and }\end{array}$ & 19.2 & 16.7 & 18.1 & 15.8 & 21.4 & 18.7 & 26.8 & 24.5 \\
\hline $\begin{array}{l}\text { communica-tion } \\
\text { Power industry }\end{array}$ & 15.1 & 13.1 & 14.1 & 12.1 & 16.7 & 14.7 & 18.8 & 16.6 \\
\hline Social infrastruc-ture & 2.7 & 2.0 & 3.6 & 2.7 & 4.0 & 3.1 & 4.3 & 3.3 \\
\hline
\end{tabular}

It is clear, that different vital values of uneven-age workers, representatives of different regions, ethnics and faiths, who have appeared for a long time to be roommates of a rotational hostel, can lead (and bring) to conflicts, negative impacts on a psycho-emotional state of a rotational worker, conditions for rest after intense shifts. The shift workers arriving to the north from different regions bring here values of their subcultures, which quite often face and fight among themselves.

At the same time, there is an element of social infrastructure, which cannot be created here at any investments. This is a social and spiritual space including parents and other relatives, grandmothers and grandfathers, cemetery where dear people are buried. 
Therefore, even many northerners - stationary workers have difficulties with self-identification, they are not sure, where their house is: here in the north, where they live for a tame long or the place, from where they arrived. Even those who led the big part of the in conscious life in the north, have the feeling of 'a temporary worker'.

The long distance commuting method as a social phenomenon reminds the peculiar iceberg which top is periodic movements of the person from the residence place to a work place, and actually containing the diverse social phenomena and the processes connected with features of shift workers activity, their realization of production tasks, adaptations and socialization in nonconventional conditions, including both development and settling of new territories, creation of new social and territorial communities, etc. The adverse effects on a body of a long distance long distance commuting work method are rather diverse, for example, a long stay with the same little-known people.

The North does not only give, but also it takes from - there is lack of oxygen in the conditions of Far North, a scarcity of it is about $30 \%$ in comparison with a midland of Russia. The chronic lack of oxygen, critical pressure differences during a short period of time lead to the development of cardiovascular diseases, the change of pressure level, it promotes sugar increase in blood. The results of medico-physiological researches do not recommend working in the conditions of Far North more than 5-7 years at a turn.

Hiring a person for a long distance commuting method in the north, the employer surely checks health state of candidates who have to pass physical examination in order to prove the absence of contraindications for work in an adverse environment for a person. The Additional adverse factor of impact on health of a shift worker at a rotational method of work is continuous change of climate at arrival and departure to place of production and a place of having a rest through time and climatic zones that will definitely affect a human body. The worker, living in the West Siberian border constantly, will bear Far North working conditions easier than $f$ commuter from a midland of Russia, and furthermore from the southern regions of the country.

The labor activity of a long distance commuter is distinguished with the high emotional stress. Suffice it to say, that the average working week, depending on a schedule of work and rest, is $52-60$ hours that is significantly higher than the standard 40 working hours per week. Besides, emotional, social and geographical factors (frosts, blood-sucking insects, polar nights, need of continuous adaptation and the pre adaptation, the repeating compelled communication in the rotational settlement, the household disorders caused by a separation from a family, thoughts about children, etc.) also effect. Above-mentioned influences on the body lead to frustration, emotional "burning out" and mental diseases.

The author studied the social processes, which are connected with the rotational work in the north, since 1974, the dynamics of existent changes and contributing factors were analyzed. For this purpose, rotational workers, members of their families, experts were regularly questioned. During this field study, it appeared that the most part of rotational schedule workers (82-88\%), is satisfied with it in the whole and is not going to come back to a traditional way of life.

Meanwhile, many elements of the social situation, connected with the rotational work, have changed over the years.

So, during the Soviet period the greatest displeasure so rotational workers was caused by the organization of transport delivery, it was connected with a long expectation of transport in maladjusted for this purpose places and social service in workers' settlements. I often had to visit them and I observed how people slept on dirty flock beds without bed sheets, and rotational workers, who had just come from their work, were waiting for their beds. After a visit of a complex BP workers' settlement in Alaska, I was impressed. During the Post-Soviet period, these two problems were generally removed.

According to the workers' opinions, in recent years, the main reason for dissatisfaction and the related conflicts in rotational collectives is insufficient salaries, its delays, problems connecting with home departure. Among the reasons of possible dismissal along with low salaries, the state of health and the family circumstances connected with work are also specified. The last factor, a long separation from a family, probably, has ambiguous influence. Therefore, according to Michel Montaigne, it can play a positive role. And everyone learned it by experience - he writes - that continuous stay together does not give that pleasure what you can feel when you separate and meet again and again. These separations fill me with the updated love to my house and make my staying at home more delightful and tempting for me (Montaigne, 1992).

However, our polls of shift workers' wives did not confirm completely such an assessment. About $42 \%$ of them said an opinion that shifts influences on intimate life of their family negatively. After a long break, the tired, just returned husband failed quite often, and because of chagrin, he started to drink alcohol.

Besides shift workers evaluation of various aspects of their living by rotational works activity, for these years the geography of long distance commuting has changed also. In the Soviet period, the crews of oil industry workers operating in the Tyumen North were from Azerbaijan, gas workers- from the Ukraine, builders- from Baltic and Armenia mainly, in Post-Soviet years they were replaced by rotational workers from the Russian regions, inhabitants of Kazakhstan and 
other Central Asian countries.

As one of main problems, many of the interrogated rotational workers noted the impossibility to stay alone. Meanwhile, it is known what exactly this opportunity allows the person not only to reflex and be engaged in introspection, but also to remove a psycho emotional stress. It is sound out that with the growth of a rotational experience many workers have insomnia, feeling of emotional exhaustion, lack of appetite (or, on the contrary, an overeating), abuse of nicotine, coffee, alcohol.

The relevance of rotational work researches is not connected only with the necessity of new natural resources development of the North and the East of the country. It is important to notice the fact that long distance commuting method is almost the only opportunity to improve standard of living for many Russian settlements and the border territories of the CIS with high unemployment rate. Thus, besides problems, the long distance commuting method has also significant potential opportunities for all interconnected parties: for rotational workers and for their employers, for the northern accepting cities and for the labor donor regions. This rather flexible technology allows reducing means and time expenses for realization of goals, reacting to a dynamic market situation timely, adapting for demand changes. Besides, this method allows lowering unemployment rate significantly and stimulating social mobility of workers and members of their families, improving standard of living. Long distance commuters connect various social and economic spaces of "Continent" and the North; they influence both of them significantly.

It is clear, that in spite of the efficiency, the long distance commuting method requires much more organizational efforts than the traditional one. Besides the usual administrative functions, it requires providing transport delivery according to the scheme "the basic city - the rotational settlement - a field", social service of the rotational personnel and many other things.

In the whole, this method is economic due to its decrease on unit cost of all types of resources on foundation and maintenance of settlements in places of production and reduction number of workers living there (Tataria, Bashkiria, etc.), as well as creation of habitual living conditions for oil workers without their families relocation to a new place of residence.

Social aspects of long distance commuting method usage are not by far decisive. Although, all these years, the majority of the interrogated rotational workers also characterized it positively, without wishing to work differently, however, the objective negative factors demanding special researches are revealed.

First of all, they are connected with frequent and considerable movements in space (climate-zone contrasts, differences in time-zones, changes of food and water quality, an epidemiological and radiation situation, etc.) the increase of work intensity, physical and psycho emotional activities, an isolation from a family for a long time (disconnection from children education, change of a sexological situation), etc. Eventually, all these factors lead to considerable deterioration of human health and finally effect on health of future children adversely. Physicians' researches confirm irreversible repercussions in body changes of living in the conditions of the Far North during more than 10 years, and their recommendation about adverse effects concerning with sharp change of a climatic zone for permanent residence. Besides, life in rotational settlements and the closed-form collectives, in conditions of private space absence, requires special personal qualities: social flexibility, possession of self-realization skills, ability to adapt in a collective quickly, to accept group norms and values.

The influence of long distance commuting method on an ecological situation in the northern region is not also decisive. On the one hand, the rotational personnel stays here much less time, than resident populations, they live without their family's members, require a construction of a smaller number of social objects. Therefore, both anthropogenous load on natural landscapes and negative impact on living conditions of the native population are reduced significantly. At the same time, negative subjective repercussions of a rotational worker psychology as a temporary worker, not the owner of this land, are also obvious.

Complex social and labor problems have arisen at the Middle Ob exploration and production companies, where the volume of extraction of hydro carbonic raw materials sharply decrease and, thus, keeping of the personnel demands the use of their labor potential in other regions. It causes a high use of a long distance commuting method in work organization and further, however its paradigm radically changes: now other regions inhabitants do not fly to work on the North, and, on the contrary, more and more oil workers, living here constantly, work in the Eastern Siberia.

Since December 2012, the Utair Airline Company has performed a rotational works flights to the Talakan airport of the Sakha Republic (Yakutia) in the interests of JSC Surgutneftegaz by Boeing 737 from Surgut, where rotational workers arrive by scheduled flights operated by Utair Airline from various points. Further, the passengers continue their flight to the remote working platforms by helicopters of Utair Airline Company, which are based at the airport. The rotational workers, who have finished their work, fly back. The performance of full- service transportation by one Airline Company allows optimizing routes and delivery period of workers, saving time and reducing customers' expenses.

For the period of 2013, in the direction Surgut - Talakan - Surgut 84,218 passengers were delivered. Next years, 
taking into account the development of the Talakansky field, the increase of transportation performance through Talakan is expected. It can happen due to operating of scheduled flights for inhabitants of the remote regions of Yakutia, the Irkutsk region and the Krasnoyarsk region in the near future.

\section{Concluding Remarks}

At the same time, there are many social and administrative problems of effective realization of a rotational work organization: social well-being of workers, preservation of their health, need of quality improvement of their life, etc. The social processes, which are taking place in rotational collectives in the north, demand careful studying and development of adequate administrative mechanisms and the technologies directed on improvement of a social situation, transformation of rotational workers from "a human resource" in social actors.

It is necessary to create social technologies, which allow neutralizing the negative aspects influence of rotational work. First, it is referred to the technologies of recruitment and selection of the most suitable personnel for the rotational work conditions in the north, their adaptation, motivation to effective work, to a choice of work and rest modes, transport delivery, social service, etc. It also includes social benefits and safeguard of the rotational personnel, and mechanisms of companies' interaction with public authorities in places of continuous accommodation of the rotational personnel, as well as in the territory of their work.

A continuous scientific monitoring of rotational work using, especially interregional one, is necessary as well. It is not only question of sociological, medico biological, economic, legal, psychological and other researches, but a creation of monitoring system to follow economic changes regularly and social processes in rotational collectives, to make necessary correcting administrative decisions up to date (Rolshoven, 2004; 2006; 2009).

\section{Acknowledgement}

Authors acknowledge scientific Fung of Humanities for its support at preparing the article (Project 15-03-00367a "The level of human potential and social situation in the Arctic Region as a factor of development of fuel-energy complex").

\section{References}

Beach, R., Brezenton, D., \& Chiff, D. (2003). Workforce Turnover in FIFO Mining Operations in Australia: an Exploratory Study. Brisbane: Centre for Social Responsibility in Mining, Sustainable Minerals Institute, University of Queensland.

Belonozhko, M., \& Silin, A. (2013). Russian North: change of Social Situation Middle-East Journal of Scientific Research, 16(2), 150155.

Buscher, M., \& Urry, J. (2009). Mobile Methods and the Empirical. European Journal of Social Theory, 12(1), 99-116.

Eilmsteiner-Saxinger, G. (2011). "We Feed the Nation": Benefits and Challenges of Simultaneous Use of Resident and long-distance Commuting Labour in Russiais Northern Hydrocarbon Industry. The Journal of Contem Porary Jssues in Business Government, $17,53-67$.

Eilmsteiner-Saxinger, G. (2013). "Bodenschatze und Menschenschatze - Zur soialen and materialen Dimension der fossilen Rohstoffe in Nordwest - Sibirien in Kontext des Fernpendelns" In: S. Donecker, J. Eberhard \& M. Hirnsperger (eds.) Wege rum Norden Wiener Forschungen zu Arktis und Subarktis (pp. 23-43). Wien LIT.

Hilti, N. (2009). Tere, there and in-Between: On the Interplay of Multilocal Living, Space and Inequality. In T. M. Ohnmacht \& M. M. Bergman (eds.) Mobilities and Inequality (pp. 145-164). Farnham: Ashgate.

Khaytun, A. (2013). Long-distance commute work in post-soviet Russia. Proceedings of the International Symposium "Contemporary issues in long - distance commute work in the extractive industries and other sectors". University of Vienna, Austria.

Mokenzie, F.H., \& Hoath, A. (2013). Examining the socio-economic Impacts of long distance commuting on labor Source communities in Western Australia. Proceedings of the International Symposium "Contemporary issues in long - distance commute work in the extractive industries and other sectors". University of Vienna, Austria.

Montaigne, M. (1992). Experiments. Selected works in 3 volumes. Moscow: Golos.

Olwig, K.F., \& Sorensen, N.N. (2002). Mobile livelihoods: Making a living in the world. In: Work and migration: Live and livelihoods in a globalizing world (pp. 1-9). London, Routledge.

Rolshoven, J. (2004). Mobilitat and Multilokalitat als moderne Alltagspraxen Ethnographien kultureller Mobilitat. In U. Gyr \& J. Rolshoven (eds.) Zweitwohnsitze and culturelle Mobilitat. Projektberichte (pp. 19-27). Zurich: Volkskundliches Seminar.

Rolshoven, J. (2006). Woanders daheim. Kulturwissenschaftliche Ansatze zuz multilokalen Lebensweise in der Spatmoderne. In: J. Rolchoven (eds.) Mobility and social Change Mobilitat and Sozialer Wangel. A choice of texts. [Online] Available: http://www.unigzaz.at/johanna.rolshoven/jr textauswahl.pdf (March 29, 2013).

Rolshoven, J., \& Winkler, J. (2009). Multilokalitat and Mobilitat. Informationen zuz Raumentwicklung, 1(2), 99-106.

Rosstat (2012). Economic and Social Indicators of the Far North regions and districts equated to them. 
Schier, M. (2013). Doing Family under conditions of job mobality and multilocality. Proceedings of the International Symposium "Contemporary issues in long - distance commute work in the extractive industries and other sectors". University of Vienna, Austria.

Silin, A. (2011). Interregional use of Human Resources on the Far North. Socis, 9, 41-47.

Southcott, S. (2013). Long distance commuting and impacts on Northern communities; a new research Agenda. Proceedings of the International Symposium "Contemporary issues in long - distance commute work in the extractive industries and other sectors". University of Vienna, Austria.

Storey, K. (2001). Fly-in / Flu-out and Fly-over: Mining and regional development in western Australia, Australian Geographer, 32(2),133148.

Storey, K. (2008). The evolution of commute work in Canada and Australia. In: Biography, shift-labour and socialization in a Northern Industrial City-The Far North: Particularities of lab our and Human socialization (pp. 23-32). Novi Urengoy.

Storey, K. (2010). Fly-in / Fly-out: Implications for Community Sustainability. Sustainability, 2, 1161-1181.

Weichhart, P. (2009). Multilocalitat Konzepte, Theorie bezuge und Forschungsfragen. Informationen zus Raumentwicklung, 1 (2), 1-14. 